monosomy $13 \mathrm{q} 32 .{ }^{5}$ Conversely, deficiency of band $13 q 33$ appears to be associated with a different phenotype without the typical head profile and thumb anomalies. ${ }^{3}$ The association of coagulation defects with (probable) loss of 13q34 observed in two unrelated patients ${ }^{5}$ was not found in our case 2 . Our findings, together with the absence of coagulation disorders in the majority of 13 qter monosomy cases, do not support the proposed relationship between monosomy 13q34 and deficiency of factors VII and $X .{ }^{5}$ Such a defect may rather be an unspecific and inconstant finding in some chromosomal disorders as it has also been observed in three cases of trisomy $8 .^{9}$

To conclude, the observations reported here contribute to the establishment of the phenotypic mapping of chromosome $13,{ }^{78}{ }^{10}$ which nevertheless remains incomplete.

The authors wish to thank A Alcaraz for the art work.

\section{Addendum}

Recently, de Grouchy et al (Hum Genet 1984;66: 230-3) have provided additional evidence for the assignment of the structural genes of clotting factors VII and X to $13 q 34$. Whether the coagulation in our cases is indeed abnormal remains uncertain.

\section{References}

1 Allderdice PW. Davis JG. Miller OJ, et al. The 13q- deletion syndrome. Am J Hum Genet 1969:21:499-512.

2 Turleau C, Séger J, de Grouchy J, Doré F. Job JC. Del (13)(q33). Exclusion de estérase D (ESD) de 13q33 et q34. Ann Genet (Paris) 1978;21:189-92.

${ }^{3}$ Emanuel BS. Zackai EH. Moreau L. Coates P. Orrechio E. Interstitial deletion $13 q 33$ resulting from maternal insertional translocation. Clin Genet 1979;16:340-6.

${ }^{4}$ Telfer MA, Clark GE, Casey PA, Cowcll HR, Stroud HH. Long arm deletion of chromosome 13 with exclusion of esterase D from 13q32 $\rightarrow$ 13qter. Clin Genet 1980;17:428-32.

5 Pfeiffer RA, Ott R, Gilgenkrantz S, Alexandre P. Deficiency of coagulation factors VII and X associated with deletion of a chromosome 13 (q34). Evidence from two cases with 46, XY.t(13; Y)(q11;q34). Hum Genet 1982;62:358-60.

${ }^{6}$ Gilgenkrantz S. Pierson M. Mauuary G. Chromosome 13q+ par translocation probable d'un Y surnuméraire. Ann Genet (Paris) 1973:16:167-72.

7 de Grouchy J, Turleau C. Atlas des maladies chromosomiques. 2nd ed. Paris: Expansion Scientifique Française, 1982:241-3.

${ }^{x}$ Niebuhr E. Partial trisomies and deletions of chromosome 13. In: Yunis JJ, ed. New chromosomal syndromes. New York: Academic Press, 1977:273-99.

${ }^{9}$ de Grouchy J. Josso F. Beguin S. Turleau C, Jalbert P, Laurent C. Déficit en facteur VII de la coagulation chez trois sujets trisomiques 8. Ann Genet (Paris) 1974;17:105-8.

1" Rivas F, Rivera H, Plascencia ML, Ibarra B, Cantú JM. The phenotype in partial $13 q$ trisomies, a propos of a familial $(13 ; 15)(\mathrm{q} 22 ; \mathrm{q} 26)$ translocation. Hum Genet 1984:67:86-93.

Correspondence and requests for reprints to $\mathrm{Dr} \mathrm{H}$ Rivera, División de Genética, Subjefatura de Investigación Científica, Unidad de Investigación Biomédica, Centro Médico de Occidente, Instituto Mexicano del Seguro Social, Apartado Postal 1-3838, Guadalajara, Jalisco, Mexico.

\title{
Congenital diaphragmatic hernia in half sibs
}

\section{A H LIPSON AND G WILLIAMS}

Birth Defects and Neonatal Units, Royal Alexandra Hospital for Children, Camperdown, NSW 2050, Australia.

SUMMARY Half brothers from the same mother had congenital left sided posterolateral diaphragmatic hernias repaired in the neonatal period. The inheritance of diaphragmatic hernia should probably be based on the multifactorial hypothesis.

There are two types of developmental defects of the diaphragm, posterolateral defects or Bochdalek hernia and retrosternal defects or Morgagni hernia. Other, more extensive, defects can involve most or all of the hemidiaphragm. Eventration of the diaphragm and hiatus hernia will not be considered. The patient usually presents in the first hours or days of life with respiratory distress. The condition is amenable to surgical repair, the first successful cases having been treated in the 1940s. We wish to report left sided posterolateral diaphragmatic hernias in two half brothers from the same mother and review published reports concerning the familial incidence of diaphragmatic hernia.

\section{Case report}

The first child, a male, was born at term weighing 
$3.2 \mathrm{~kg}$ and he developed respiratory distress in the first 12 hours. A left sided diaphragmatic hernia was diagnosed and a posterolateral defect was repaired on the first day of life. The child was subsequently noted to have malrotation of the small bowel and a left undescended testis which was repaired at the age of 2 years. There were no other abnormalities or dysmorphic features. Subsequent physical and developmental progress has been satisfactory. After two further normal male children the mother divorced and remarried. The first child of the subsequent marriage, a male, was born at term weighing $3.6 \mathrm{~kg}$ and developed respiratory distress in the first hours after birth. A left sided diaphragmatic hernia was diagnosed and a posterolateral defect repaired on the first day of life. This child had considerable problems with postoperative pulmonary hypertension but eventually made a good recovery. No other abnormalities or dysmorphic features were noted. Based on the operative description there was no difference in the size of the hernia between the two sibs. Repair was affected without grafting and there was ample redundant diaphragmatic muscle. The second affected child also had a left undescended testis. The fathers were unrelated. The mother is adopted and has a normal chest $x$-ray.

\section{Discussion}

In the 31 familial cases of diaphragmatic hernia recorded, ${ }^{1-14}$ all but three were in sibs. The exceptions were first cousins, $"$ " an uncle and two nephews, ${ }^{2}$ and a nephew of three affected sibs. ${ }^{13}$ Two sibs were identical twins. ${ }^{14}$ There have been no case reports of transmission from parent to child, though Mertins ${ }^{7}$ noted a high diaphragm in the mother of two affected children. All the cases either had a posterolateral defect or aplasia of one or both hemidiaphragms.

Recurrence of diaphragmatic hernia in a family may be underestimated, as may be the true incidence in a newborn population. In Butler and Claireaux's study ${ }^{15}$ the lesion was present in 1 in 2200 births ( 1 in 1100 stillborns and 1 in 4000 live births) and comprised $8 \%$ of all major congenital anomalies. It is certain that, at least until recently, neonatal surgical centres received only a proportion of the better risk patients. In an early study 1 in 8000 to 1 in 10000 live births were referred to a neonatal surgical centre with diaphragmatic hernia. ${ }^{16} \mathrm{~A}$ more recent study with full ascertainment of cases from a university hospital has revealed an incidence of 1 in 2644 births. ${ }^{17}$ Reports of increased incidence are therefore probably due to greater ascertainment. ${ }^{18}$ Presumably some cases used to be unrecognised, presenting either as a stillbirth or as fatal respiratory $\stackrel{\overrightarrow{\mathrm{D}}}{\rightarrow}$ distress of the newborn. Wolff ${ }^{1}$ found two familial $\Rightarrow$ cases by checking a 10 year necropsy series, Butler $\stackrel{\rho}{?}$ and Claireaux ${ }^{15}$ found one familial case in their necropsy series, and David and Illingworth ${ }^{19}$ had $\stackrel{\overline{\underline{T}}}{2}$ four unexplained cases of neonatal mortality among $\frac{\bar{D}}{\vec{D}}$ 181 sibs of patients with diaphragmatic hernia.

The causes of diaphragmatic hernia are heterogeneous, being associated with chromosomal $\vec{\theta}$ trisomies, ${ }^{19}$ teratogenic agents, ${ }^{2}{ }^{20}$ and recognisable? patterns of malformation. ${ }^{1}$ About $50 \%$ of all cases $\vec{\omega}$ have other congenital malformations, in particular $\stackrel{\circ}{\circ}$ related to the central nervous system. ${ }^{19}$ Excluding $\overline{3}$ persistent ductus arteriosus and malrotation of the bowel (which is embryologically linked), only nine $N$ of 66 familial cases had a reported associated $\stackrel{N}{?}$ malformation, usually related to the cardiovascular $\vec{f}$ system. In addition, a bilateral lesion is up to seven 0 times more likely in the familial cases. ${ }^{3}$

Passarge et $\mathrm{al}^{6}$ argued that aplasia of the dia- $\vec{\nabla}$ phragm may be a distinct entity with autosomal recessive inheritance. His description is insufficient to exclude a large posterolateral defect with a rim of $\varrho_{\infty}$ diaphragm. ${ }^{2}$ Five families have been reported in .5 which there is discordance in the extent of the defect, with one child having a posterolateral lesion and a sib having a large defect or aplasia. 257810 The paucity of consanguineous cases, ${ }^{3}{ }^{13}$ and the marked excess of males $(40: 21)$ in the familial cases $\stackrel{\square}{\square}$ compared to the group as a whole, ${ }^{19}$ are uncharac- $\vec{\not}$ teristic of autosomal recessive inheritance. Sex 응 linked or autosomal dominant inheritance with incomplete penetrance have been proposed as modes of inheritance, ${ }^{2}$ but do not fit all the extended pedigrees. The multifactorial model is the most likely type of inheritance because of the male predominance, the compatibility of all pedigrees, including the cases reported here in half sibs, and 8 the exclusion of other modes of inheritance to account for all familial cases. Occasional consan- 0 guinity is compatible with multifactorial inheritance presuming that each side carries some of the polygenic predisposing genes. ${ }^{13}$ Expected recurr ence rate in first degree relatives can be calculated $\mathscr{N}$ using the formula $\sqrt{\mathrm{P}}$ where $\mathrm{P}$ is the frequency in $N$ the general population. ${ }^{21}$ Taking the figure of But'er $N$ and Claireaux ${ }^{15}$ of 1 in 2200 , a 1 in 47 or $2 \%$ risk van $\sigma$ be expected, keeping in mind that a significant proportion may be perinatal deaths. The abserce of $\stackrel{\circ}{=}$ associated malformations and the presence of a $\stackrel{\oplus}{\oplus}$ bilateral lesion would increase a recurrence risk. Genetic heterogeneity cannot, however, be ex- 0 cluded and conclusions from the combined data may $\overrightarrow{\mathbb{D}}$ be inappropriate. No case has yet been reported in $\frac{}{\mathbb{Q}}$ parent and child, though this should occur if the multifactorial basis is indeed correct. 
We thank Dr M J Glasson for permission to report the cases.

\section{References}

1 Wolff G. Familial congenital diaphragmatic defect: review and conclusion. Hum Genet 1980:54:1-5.

2 Cranc JP. Familial congenital diaphragmatic hernia. Clin Genet 1979:16:244-52.

3 Arad I. Lijovetsky GC. Staninsky R. Laufer N. Cohen T. Diaphragmatic defects in children of consanguinous parents. Hum Genet 1980;55:275-7.

+ Hauschild VR. Congenital diaphragmatic hernia from the human genetic viewpoint. Kinderaerztl Prax 1982:50:16-20.

5 Gencik A, Moser H. Gencikova A. Kehrer B. Familial occurrence of congenital diaphragmatic defect in three families. Helv Paediatr Acta 1982:37:289-93.

- Passarge E. Halsey H. German J. Unilateral agenesis of the diaphram. Hum Genet 1968:5:226-30.

${ }^{7}$ Mertins H. Uber eine familiare Zwerchfellmibildung. Zentralbl Gynaekol 1952:74:951-5.

${ }^{*}$ Phillip EE. Skelton MO. Congenital diaphragmatic hernia in siblings. Br Med J 1952:i:1283-4.

${ }^{9}$ Daentl DL. Passarge E. Familial agenesis of the diaphragm. Birth Defects 1972:8:24-6.

11' Wolff G. Bohn N. Pringschein W. Congenital defects at the diaphram in siblings. Monatsschr Kinderheilkd 1980:128:412-4.

"Turpin R, Petit P. Chigot P. Lafourcade J, de Barochez Y. Hernie diaphragmatique congenital de type embryonnaire. Coincidence chez deux cousins germains de cette malformation isoléc. Ann Pediatr 1959:35:272-9.
12 Gualandri V. Lalatta F. Orsini GB. Zorzoli A. Bertagnoli L. Gallicchio A. Diagnostic prenatal d'un cas de repitition familiale. D’agenesie unilateral du diaphragme. J Genet Hum 1983:31:125-31.

13 Norio R. Kaaiainen H, Rapola J. Herva R. Kekomari M. Familial congenital diaphragmatic defects. Am J Med Genet 1984:17:471-83.

14 Watanatiitan S. Congenital diaphragmatic hernia in identical twins. J Pediatr Surg 1983:18:628-9.

15 Butler N. Claireaux AE. Congenital diaphragmatic hernia as a cause of perinatal mortality. Lancet 1962;i:659-63.

in Stauffer UG. Rickham PP. Congenital diaphragmatic hernia and eventration of the diaphragm. In: Rickham PP, Lister JP, Irving IM. eds. Neonatal surgerv. 2nd ed. London: Butterworths. 1978:163-78.

17 Harrison MR. Delorimer AA. Congenital diaphragmatic hernia. Surg Clin North Am 1981:61:1023-35.

is David TJ. Parker VM. Illingworth CA. Diaphragmatic hernia in Avon. J Med Genet 1980:17:135.

${ }^{19}$ David TJ. Illingworth CA. Diaphragmatic hernia in the southwest of England. J Med Genet 1972:13:253-62.

20 Barry JE. Danks DM. Anticonvulsants and congenital abnormalities. Lancet 1974:ii:48-9.

2 Edwards JH. The simulation of Mendelism. Acta Genet 1960:10:63-70.

Correspondence and requests for reprints to $\mathrm{Dr} \mathrm{A} \mathrm{H}$ Lipson, Birth Defects Unit, Royal Alexandra Hospital for Children, Camperdown, NSW 2050, Australia.

\title{
A case of suspected teratogenic holoprosencephaly
}

\author{
M STABILE*,A BIANCO*,S IANNUZZI†,M C BUONOCORE‡,AND \\ V VENTRUTO*
}

* Servizio Genetica Medica, Ospedale Cardarelli; †Divisione Pediatria, Ospedale San Paolo; and $¥$ Settore di Neuroradiologia, Ospedale Santobono, Napoli, Italy.

SUMMARY A case of holoprosencephaly is reported in which the mother was prescribed high doses of oestroprogestins during the first 5 months of the pregnancy. Investigation of the family failed to reveal any sign of physical abnormality. A normal karyotype was detected in the proband. The authors suggest that this case may shed some light on the normal and abnormal way in which embryonic fields develop.

The action of teratogenic factors in the aetiology of holoprosencephaly has been studied experimentally using various animals (amphibia, birds, and mammals) and different agents (surgical removal of the prechordal mesoderm or its destruction by localised $x$ irradiation, vitamin A excess, etc). ${ }^{12}$

The great majority of reports of this condition in man refer to cases with various chromosomal abnormalities, ${ }^{3-7}$ or Mendelian aetiology with autosomal dominant transmission in some families ${ }^{x-10}$ and autosomal recessive in others. ${ }^{111}$

Only a very few reported cases ${ }^{12}$ have well documented teratogenic mechanisms as causative factors. In the other cases Mendelian or chromosomal aetiology cannot be ruled out.

We report a case of alobar holoprosencephaly with a known exposure to a teratogenic agent.

\section{Case report}

The proband (fig 1) was a term newborn male (birth weight $3.5 \mathrm{~kg}$, head circumference $40 \mathrm{~cm}$ ) who died 